\title{
PERDEGIMO SINDROMO POVEIKIS ERGOTERAPEUTŲ PROFESINIAM TOBULE்JIMUI
}

\author{
Luka Tichonova, Milda Gintilienė \\ Kauno kolegijos Medicinos fakultetas
}

Raktažodžiai: ergoterapija, profesinis tobulèjimas, perdegimo sindromas, stresas.

\begin{abstract}
Santrauka
Pirmą kartą perdegimo sindromo (PS) sąvoka paminèta XX a. 7 dešimtmetyje. PS apibrèžiamas kaip stresinè reakcija ị darbą, kuriam būdingas emocinis išsekimas, nuasmeninimas, cinizmas ir sumažèję asmeniniai pasiekimai. Literatūroje labai dažnai apibūdinamas kaip sindromas, kuriam būdingas emocinis ir fizinis išsekimas, dèl kurio žmogus negali pasveikti. Vis dažniau pradètas minèti bei analizuoti PS tapo plačiai ištirtu reiškiniu. Lietuvoje atliekama nemažai tyrimų, vertinančių medicinos darbuotojų PS, tačiau trūksta tyrimų, kuriuose būtų analizuojamas ergoterapeutų PS. Atlikus mokslinès literatūros analizę, nerasta Lietuvoje atliktų tyrimų, kurie vertintų šios tikslinès grupès profesinio tobulèjimo nuostatas ir jų ryši su PS. Tyrimo tikslas ìvertinti perdegimo sindromo poveikị ergoterapeutu profesiniam tobulejimui. Tyrimo metodai. Anoniminès anketinès apklausos metodu buvo apklaustas 91 ergoterapeutas. Pasirinkta imtis - patogioji tiriamuju atranka. Klausimyną sudarè profesinio tobulèjimo, sociodemografiniai, Kopenhagos perdegimo sindromo vertinimo klausimai. Atlikta gautų rezultatų aprašomoji analize, aprašomoji statistika, taikant Microsoft Office Excel 2019 biuro programą. Gauti duomenys pateikti skaitinèmis (procentinèmis) išraiškomis. Rezultatai. Apibendrinus tyrimo rezultatus nustatyta, kad Lietuvoje dirbantys ergoterapeutai (90 proc.) patiria vidutinio lygio perdegimo sindroma, o profesinio tobulèjimo srityje aukštai vertina savo bendradarbiavimo $(49,5$ proc.), bendravimo (35,2 proc.), profesinio tobulëjimo (29,7 proc.) ir pokyčių inicijavimo (27,8 proc.) kompetencijas. Didžioji dalis (46,2 proc.) tiriamujų visiškai sutinka, kad dalyvauja profesinio tobulejjimo veiklose ir tai jiems padeda.
\end{abstract}

\section{Ivadas}

Sveikatos priežiūros specialistams, kurių darbo pobūdis siejamas su didele protine ir emocine įtampa, būdingas perdegimo sindromas (PS). Pasaulio sveikatos organizacija (2020) PS apibrěžia kaip sindromą, kuris atsiranda veikiant lètiniam stresui darbo vietoje. PS būdinga energijos trūkumas bei išsekimas, stengimasis atsiriboti nuo darbo ir su darbu susiję neigiami jausmai, sumažèjęs profesinis efektyvumas [1].

Ilgainiui PS gali lemti motyvacijos darbui ir empatijos pacientams praradimą, nepasitenkinimą darbu, o tai kelia pavojų pacientų saugumui [1]. PS nustatomas dažniau tose profesijose, kuriose darbas glaudžiai siejamas su pagalba žmonėms. Perdegimas dažnai traktuojamas su viršvalandžiais, didele atsakomybe, nerimu bei nusivylimo ir bejègiškumo jausmu, dirbant su sunkiomis ligomis sergančiais žmonemis. Jaunesniems medicinos specialistams dažnai pritrūksta ịgūdžių ir praktinių žinių spręsti darbo vietoje kylančias problemas [2]. Nuo perdegimo asmens negali apsaugoti nei amžius, nei pareigos, nei specialybė [3].

Ivertinus PS aspektus, nustatytas žemas ergoterapeutu emocinio išsekimo laipsnis, vidutinis depersonalizacijos ir asmeninių pasiekimų laipsnis. Nustatytas beveik visų Lietuvoje dirbančių ergoterapeutų aukštas depersonalizacijos laipsnis, nepriklausomai nuo išsilavinimo, lyties bei amžiaus [4]. J.A.M.C. Kim ir kt. tyrëjų (2020) [6] atlikto tyrimo rezultatai skirtingose ligoninèse parode, kad jaunesni ergoterapeutai patiria aukštesnius perdegimo balus, palyginti su vyresniais tyrimo dalyviais, nes vyresnių specialistų duomenys parode didesni pasitenkinimo darbu lygị, o tai galètų būti susiję su darbe reikalingais ịgūdžiais. M. Katsiana ir kt. (2021) atlikto tyrimo rezultatai parode, kad iš tirtu 345 Kipro bei Graikijos ergoterapeutu maždaug 50 proc. patiria dideli profesini perdegima, o apie 50 proc. neturi psichologinio atsparumo. Šiuos rezultatus galima interpretuoti kaip kokybiško darbo bei profesinių tikslų pasiekimo problemą [5]. Veiklos, susietos su profesiniu tobulèjimu, leidžia labiau įsitraukti ị naujus profesinius siekinius ir plèsti žinias 
praktikoje. Profesinis tobulejjimas ne tik plečia žinias, bet ir tobulina bendravimo, komandinio darbo ir bendradarbiavimo ịgūdžius [5].

Perdegimo sindromo prevencijai taikoma daug skirtingų priemonių ir būdų. Skirtingus prevencijos būdus nagrinèję mokslininkai priejjo prie bendros išvados - perdegimo sindromo pasireiškimas ir simptomai kiekvienam asmeniui pasireiškia individualiai, todèl ir prevencijos priemones reikia taikyti individualiai [7]. C. Wilding ir G. Whiteford (2009) [8] atliktas tyrimas atskleide, kad ergoterapeutai, dalyvaudami su profesiniu tobulejjimu susijusiose veiklose, geriau suvokè ir patobulino praktinius ịūdžius, padidino pasitikèjimą savimi ir labiau patenkino savo, kaip ergoterapeutų vaidmenį, o visa tai padidino pacientų motyvaciją įsitraukti ị ergoterapinę veiklą. Nuolatinis profesinis tobulejjimas leidžia sėkmingai spręsti iškilusias problemas darbo aplinkoje, apsisaugant nuo rizikos perdegti. Savęs tobulinimas ir perdegimo rizika yra glaudžiai susiję su gebejjimu teikti kokybiškas paslaugas [4].
Tyrimo tikslas - įvertinti perdegimo sindromo ịtaką ergoterapeutų profesiniam tobulèjimui.

\section{Tyrimo medžiaga ir metodai}

Tyrimas atliktas 2021 metų sausio - balandžio mėnesiais. Kiekybinių tyrimo duomenų rinkimui taikyta anoniminè anketiné apklausa, skirta ergoterapeutams. Kiekvienas tiriamasis anketos preambuleje buvo informuotas apie tyrimo konfidencialumą, tikslą bei eigą. Tyrimo dalyviai - ergoterapijos specialistai. Pasirinkta patogioji tiriamujų atranka - tyrime galèjo dalyvauti visi ergoterapijos specialistai, užpildę anoniminès apklausos internetu anketą. Iš viso tyrime dalyvavo 91 ergoterapijos specialistas iš visos Lietuvos. Klausimyną sudarè:

1) preambulè, kurioje tiriamieji buvo informuoti apie tyrimo instituciją, tyrèją, tyrimo tikslą bei prasmę;

2) bendroji dalis, skirta įvertinti tiriamujjų amžių, lytį, išsilavinimą, darbo stažą;

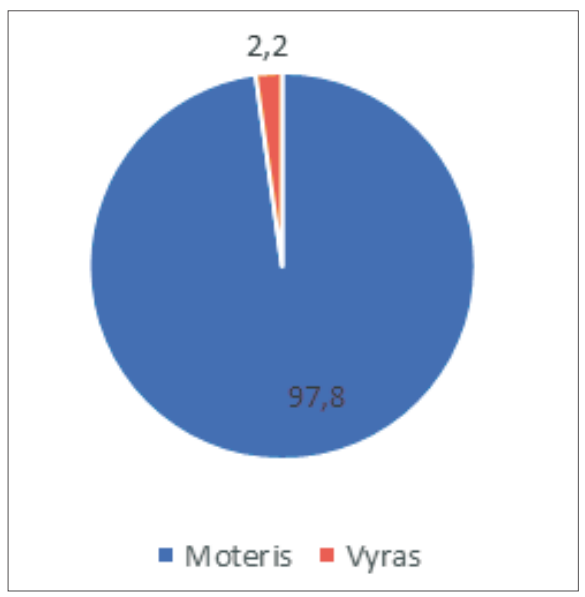

1 pav. Respondentų skirstinys pagal lytị, proc.

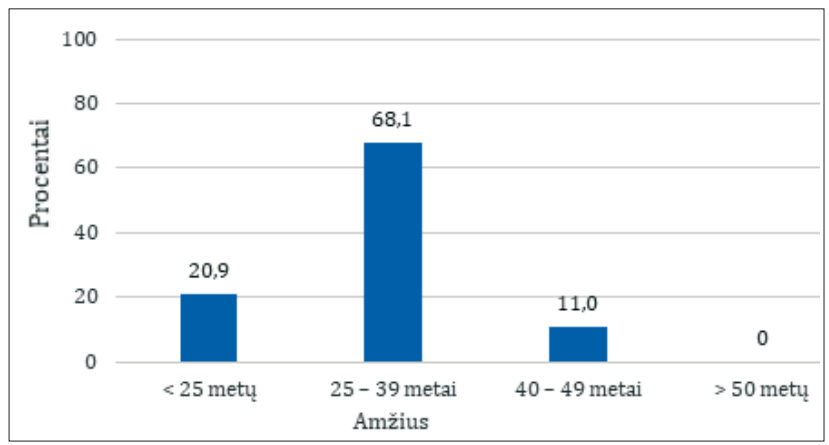

2 pav. Respondentų skirstinys pagal amžių

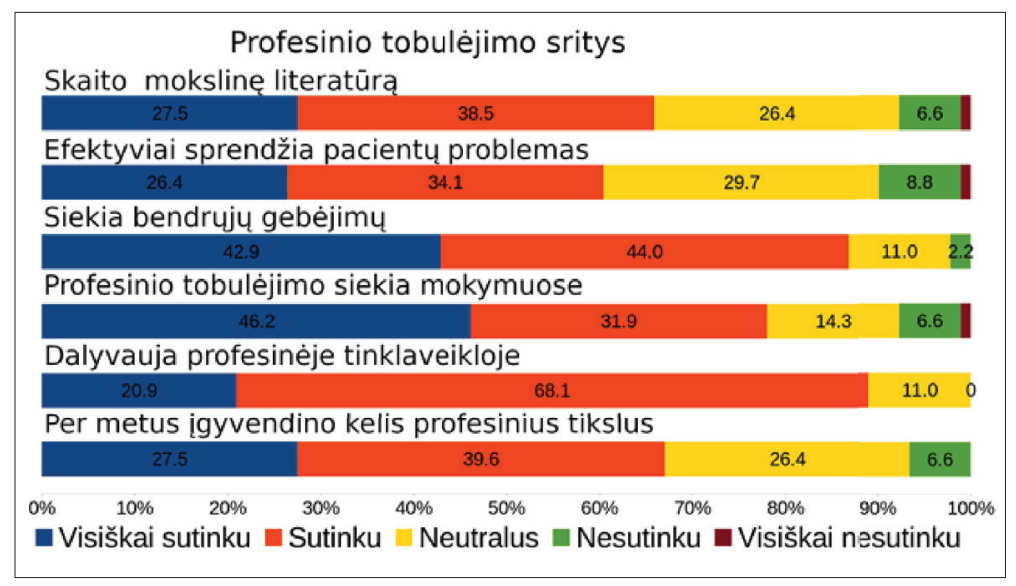

3 pav. Ergoterapeutų ịsivertinimas profesinio tobulèjimo srityse

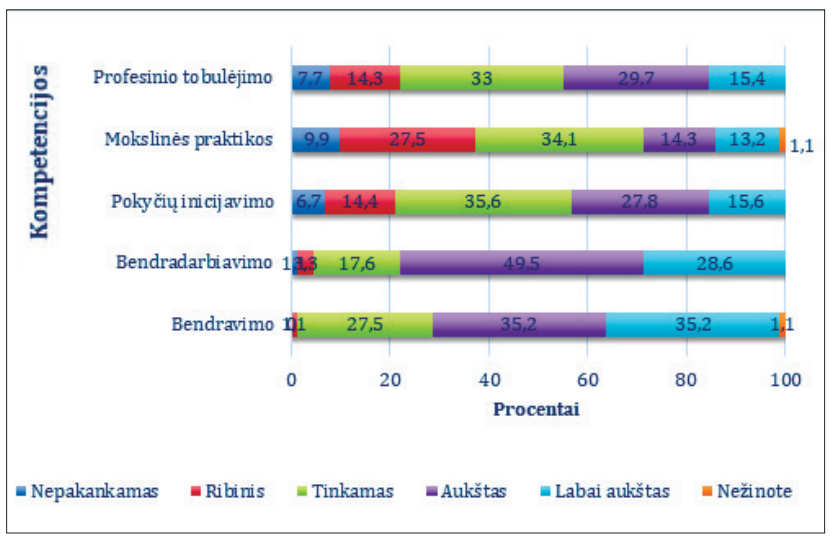

4 pav. Ergoterapeutų kompetencijų įsivertinimas 


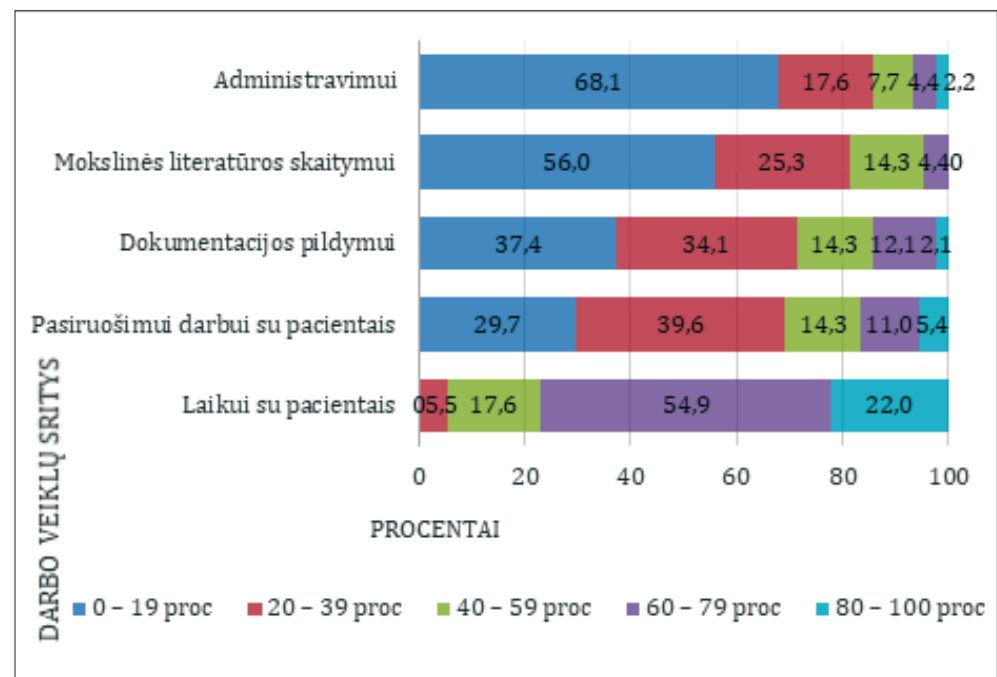

5 pav. Ergoterapeutų veiklos rūšių vertinimas

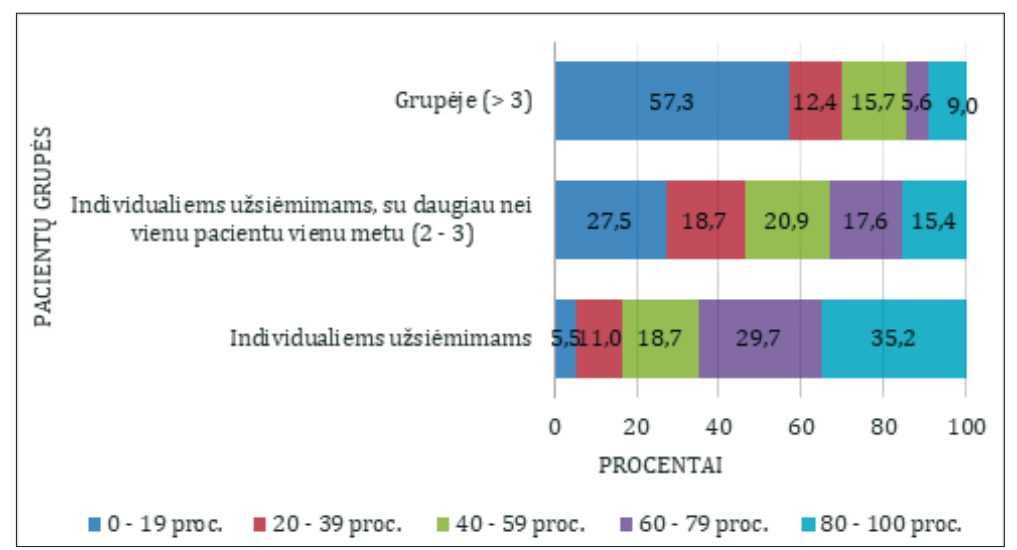

6 pav. Ergoterapeutų tiesioginio darbo laiko su pacientais vertinimas

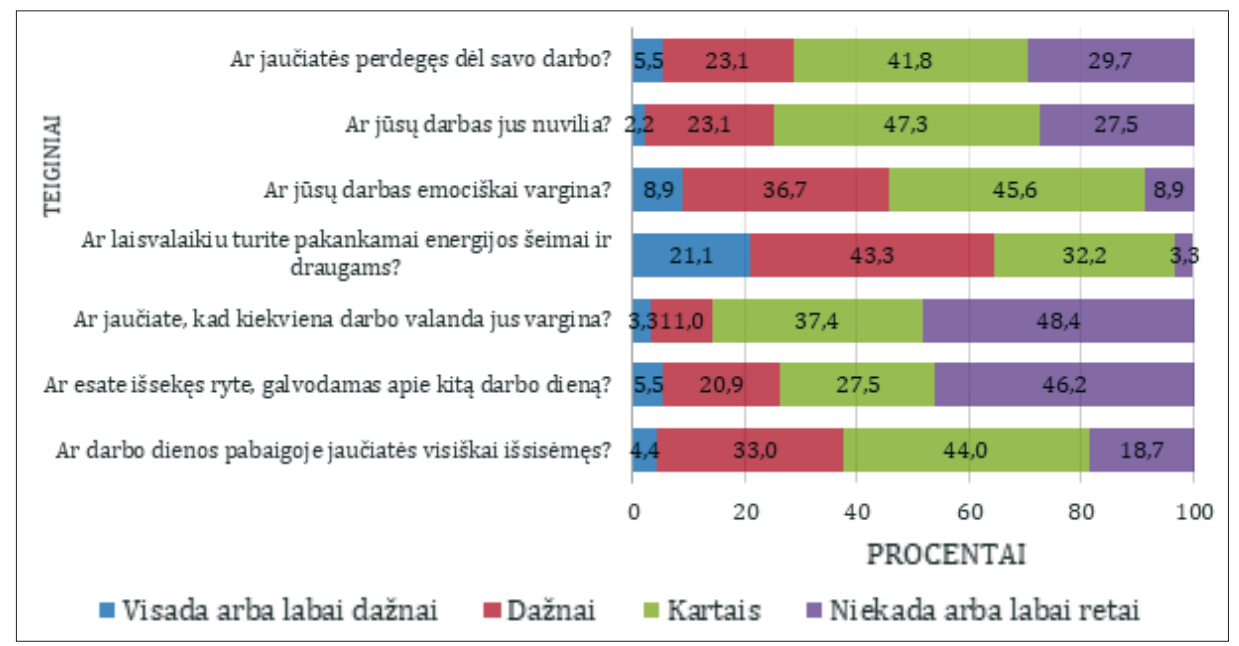

7 pav. Ergoterapeutų su darbu susijusio perdegimo vertinimas
3) perdegimo sindromo vertinimo klausimai, taikant ,Kopenhagos perdegimo sindromo vertinimo klausimyną“ (angl. Copenhagen Burnout Inventory, CBI), kuriame tiriamųjų klausiama apie jų asmeninį, su darbu bei su pacientais susijusi perdegimą;

4) profesinio tobulejjimo nuostatų vertinimo klausimai apie savo profesinị tobulèjimą, kompetencijų lygị, darbo veiklų ir tiesioginio darbo laiko su pacientais vertinimą.

Atlikta kiekybinių duomenų analizè, aprašomoji statistika, taikant Microsoft Office Excel 2019 biuro programą. Gautieji duomenys pateikti skaitine ir procentine išraiška. Remiantis gautais rezultatais, suformuluotos išvados ir pateikiamos rekomendacijos.

\section{Rezultatai ir jų aptarimas}

Tyrime dalyvavusių ergoterapeutų didžiają dali sudare moterys ( 97,8 proc.) ir tik 2,2 proc. tiriamujų sudare vyrai (1 pav.). Siekta ịvertinti tiriamųjų perdegimo lygị ir nustatyti, ar yra ryšys tarp ergoterapeutų patiriamo perdegimo sindromo ir profesinio tobulejjimo.

Respondentai buvo suskirstyti i keturias amžiaus grupes (2 pav.). Didžioji dalis $(68,1$ proc.) tyrime dalyvavusių ergoterapeutų priklausė 25-39 metų amžiaus grupei, apie penktadalis (20,9 proc.) - jaunesnių nei 25 metu amžiaus grupei, mažiausia dalis (11,0 proc.) tiriamujjų priklausė 40- 49 metų amžiaus grupei, o vyresni nei 50 metų ergoterapeutai tyrime nedalyvavo.

Tyrimo metu buvo siekiama ịvertinti tiriamujų profesinio tobulejjimo nuostatas (3 pav.).

Remiantis gautais rezultatais, daugiausiai (46,2 proc.) tyrime dalyvavusių ergoterapeutų, siekdami profesinio tobulèjimo, lankosi konferencijose, seminaruose, paskaitose. Didžioji jų dalis teigia visiškai sutinkantys (42,9 proc.) arba sutinkantys (44,0 proc.), kad profesinio tobulejimo seminarai jiems padeda tobulinti savo žinias. Daugiau kaip pusè tyrimo dalyvių ( 68,1 proc.) su- 
tinka ir penktadalis (20,9 proc.) visiškai sutinka, kad geba efektyviai spręsti ịvairias pacientų problemas. Tiriamieji sutinka ir visiškai sutinka, kad siekdami profesinio tobulejjimo, skaito mokslinę literatūrą (atitinkamai 27,5 ir 39,6 proc.). Nustatyta, kad dauguma tyrime dalyvavusių ergoterapeutu per pastaruosius metus igyvendino keletą tikslų, kurie padejjo jiems tobuleti. Su šiuo teiginiu sutinka 38,5 proc. ir visiškai sutinka 27,5 proc. tiriamujų. Labai panašus pasiskirstymas buvo ir tarp tų respondentų, kurie dalyvauja profesinèse diskusijose socialiniuose tinkluose, skaito ịvairias profesines naujienas, dauguma sutinka (34,1 proc.) ir visiškai sutinka ( 26,4 proc.) taip tobulinantys savo profesines nuostatas. Tyrimu nustatyta, kad daugiausia ergoterapeutų bendravimo kompetenciją vertina kaip labai aukštą. Aukšta dažniausiai laikoma bendradarbiavimo kompetencija. Beveik trečdalis respondentų mokslinès praktikos kompetenciją vertina kaip ribinę (4 pav.).

Siekiant įvertinti ergoterapeutu profesinį tobulëjimą, tyrimo metu buvo nustatyta, kiek laiko jie skiria tam tikrai veiklos rūšiai, susijusiai su jų profesija ir darbu (5 pav.). Remiantis gautais duomenimis, didžioji dauguma $(68,1$ proc.) tiriamujų nurodè, kad mažiausiai laiko (0-19 proc.) skiria administravimui. Daugiau kaip pusè ( 56,0 proc.) tiek pat laiko skiria ir mokslinès literatūros skaitymui. Ketvirtadalis (25,3 proc.) šiai veiklos rūšiai skiria 20-39 proc. savo laiko. Dokumentacijos pildymui daugiau nei trečdalis tiriamujų nurodè skiriantys mažiausią (0-19 proc.) arba beveik vidutinę laiko dali (20-39 proc.), atitinkamai 37,4 ir 34,1 procento. Dauguma respondentų nurode, kad pasiruošimui darbui su pacientais skiria nuo mažiausios (0-19 proc.) savo darbo laiko dalies iki beveik vidutinès (20-39 proc.), atitinkamai 29,7 bei 39,6 procento. Darbui su pacientais daugiausia $(54,9$ proc.) tiriamųų skiria daugiau kaip pusę savo laiko (60-79 proc.). Beveik visą savo laiką (80-100 proc.) šiai veiklos rūšiai skiria šiek tiek daugiau nei penktadalis ergoterapeutu (22,0 proc.).

Tyrimo metu nustatyta, kiek laiko ergoterapeutai per pastaruosius metus skyrè darbui su pacientų grupèmis (6 pav.). Pagal gautus duomenis, daugiausiai savo darbo laiko (80-100 proc. ir 60-79 proc.) tiriamieji skyre individualiems užsièmimas (atitinkamai 35,2 ir 29,5 proc.). Individualiems užsiẻmimams, kuriuose dalyvavo 2-3 pacientai, daugiau kaip ketvirtadalis $(27,5$ proc.) tyrimo dalyvių skyrė mažiausiai laiko (0-19 proc.). Daugiau kaip pusè (57,3 proc.) ergoterapeutų nevedè grupinių užsièmimų, kadangi tam skyrè tik 0-19 proc. savo darbo laiko.

Siekiant nustatyti ergoterapeutu perdegimo sindromo lygi, gauta, kad didesnè jų dalis dažnai jaučiasi pavargę (7 pav.). Daugelis teigè, kad kartais būna fiziškai, emociškai išsekę, mano, kad nebegali ištverti arba jaučiasi visiškai iš- sisėmę. Vis dèlto beveik pusė labai retai arba niekada nesijaučia esantys silpni ir imlūs ligoms.

Taip pat Analizuojant rezultatus susijusius su ergoterapeutu perdegimu susijusius rezultatus nustatyta, kad apie trečdalis dienos pabaigoje dažnai jaučiasi išsisemęe, tačiau laisvalaikiu vis tiek turi pakankamai energijos šeimai ir draugams, nors dažnai darbas emociškai vargina. Daugelis nurodè, kad labai retai arba niekada negalvoja, kaip yra išsekę jau ryte, arba kad juos vargina kiekviena darbo valanda.

Apibendrinant galima teigti, kad stipraus ryšio tarp savo kompetencijų lygio vertinimo ir asmeninio perdegimo nenustatyta. Dažniausiai tiriamieji savo kompetencijas priskyrè tinkamam lygiui, o perdegimo būseną dažniausiai nurodè jaučiantys kartais. Galima manyti, jog didejjant ergoterapeutų perdegimo lygiui, gali mažèti asmeninis kompetencijų vertinimas. Tam įtakos gali turèti nustatytas su darbu susijęs perdegimas, kurị didžioji dalis tiriamujjų nurodè patiriantys kartais, o kai kuriais aspektais, pvz. emocinio išsekimo ir išsekimo darbo pabaigoje - dažnai. Šis perdegimas vidutiniškai neigiamai veikia ir ergoterapeutų skiriamą laiką tiesioginiam darbui, kadangi dauguma tyrimo dalyvių nurodè, jog daliai savo funkcijų skiria labai mažą laiko dalị (apie 20 proc.). Galima manyti, kad patiriamas perdegimas mažina motyvaciją darbui.

\section{Išvados}

1. Lietuvoje dirbantys ergoterapeutai patiria vidutinio lygio perdegimo sindromą.

2. Geriausiai ergoterapeutai vertina savo bendradarbiavimo kompetencijas. Daugiau kaip pusė apklausoje dalyvavusių ergoterapeutų geba efektyviai spręsti įvairias pacientų problemas, siekdami profesinio tobulejimo dalyvauja konferencijose, seminaruose, paskaitose.

3. Vidutinio ar aukšto profesinio perdegimo lygio specialistai rečiau linkę pritarti profesinio tobulejjimo teiginiams. Tai rodo, kad specialistai, būdami vidutinio ar aukšto profesinio perdegimo lygio, nebus labai efektyvūs įvairiose profesinio tobulejjimo srityse. Nepaisant šių tendencijų, statistiškai reikšmingo skirtumo tarp profesinio tobulejimo siekio ir perdegimo lygio nenustatyta.

\section{Literatūra}

1. Andriulionienė A. Perdegimo sindromo pasireiškimas ir įveikos strategijos x ligoninès medicinos darbuotojų profesinejje veikloje. 2017.

2. Čèsnaitė G, Krunkaitytė U, Žemaitaitis M. Burnout in everyday life of physicians: literature review. Journal of Medical Sciences 2020;8 (14):172-181.

3. Džubur A, Lisica D, Abdulahović D, Avdić D, Smajović M, Mu- 
lić M. Burnout syndrome in primary healthcare professionals. JHSCI 2018;8(2):122-7. https://doi.org/10.17532/jhsci.2018.543

4. Jurénas J, Mingaila S. Lietuvos ergoterapeutų kompetencijos ir perdegimo sindromo sąsajos. Slaugos ir reabilitacijos teorija bei praktika. Konferencijos programa ir medžiaga. 2015:17-20.

5. Katsiana M, Galanakis M, Saprikis V, Tsiamitros, D, Stalikas A. Psychological Resilience and Burnout Levels in Occupational Therapists in Greece. An Epidemiological Nationwide Research. Psychology 2021;12:84-106.

https://doi.org/10.4236/psych.2021.121006

6. Kim J, Kim A, Kim M, Kim C, Lee K, Hwang J. Burnout Syndrome and Work-Related Stress in Physical and Occupational Therapists Working in Different Types of Hospitals: Which Group Is the Most Vulnerable? Int J Environ Res Public Health 2020;17(14):122-200.

https://doi.org/10.3390/ijerph17145001

7. Rochette A, Brousseau M, Vachon B, Engels C, Amari F, Thomas A. What occupational therapists' say about their competencies' enactment, maintenance and development in practice? A two-phase mixed methods study. BMC Medical Education 2020;20(1),120.

https://doi.org/10.1186/s12909-020-02087-4

8. Wilding C, Whiteford G. From Practice to Praxis: Reconnecting Moral Vision with Philosophical Underpinnings. British Journal of Occupational Therapy 2009;72(10):434-441.

https://doi.org/10.1177/030802260907201004

\section{THE INFLUENCE OF BURNOUT SYNDROME ON THE PROFESSIONAL DEVELOPMENT OF AN OCCUPATIONAL THERAPIST}

L. Tichonova, M. Gintilienė

Keywords: occupational therapy, professional development, burnout syndrome, stress.

Summary

The concept of burnout syndrome (PS) was first mentioned in the 1970s. PS is defined as a stressful reaction in the workplace cha- racterized by emotional exhaustion, depersonalization / cynicism, and decreased personal achievement. It is very often described in the literature as a syndrome characterized by emotional and physical exhaustion that prevents a person from recovering. The importance of analysing this phenomenon is reflected in many negative effects on a person's health, quality of work and its prevalence in various professions, and this is the reason for many studies of this syndrome. Although a number of studies are being conducted in Lithuania that assess the PS of medical staff, there is a lack of research analysing the PS of occupational therapists. After the analysis of the scientific literature, no research was carried out in Lithuania that would assess the professional development attitudes of this target group and their connection with the PS. Research aim. To evaluate the influence of burnout syndrome on the professional development of occupational therapists. Methods. 91 occupational therapists were interviewed using an anonymous questionnaire. The selected sample is a convenient selection of subjects. The questionnaire consisted of: professional development, sociodemographic, Copenhagen burnout syndrome assessment questions. Descriptive analysis of the obtained results, descriptive statistics using Microsoft Office Excel 2019 office program were performed. The obtained data are presented in numerical (percentage) expressions.

Results. Summarizing the results of the research, it was established that $90 \%$ of occupational therapists working in Lithuania experiences moderate burnout syndrome, and in the field of professional development their competence is mostly high - 49.5 percent. cooperation, 35.2 percent. communication, 29.7 percent. professional development and 27.8 percent. areas for initiating change. Also, the majority of 46.2 percent. fully agrees with that participate in and develop professional development activities.

Correspondence to: milda.gintiliene@go.kauko.lt

Gauta 2021-11-14 